\title{
A tradución como apropiación: análise das estratexias tradutivas en $O$ país da saudade de P. Castro e A. e R. Villar Ponte
}

\author{
Silvia VÁZQuez FERNÁNDEZ \\ University of Exeter \\ S.Vazquez-Fernandez@exeter.ac.uk \\ Recibido febrero 2010. Aceptado abril 2011
}

\begin{abstract}
Resumo: Na época Nós, a tradución de textos literarios irlandeses ao galego tivo un papel fundamental no proceso de reconstrución da identidade nacional en Galicia. Seguindo un ideario político baseado nos conceptos de celtismo e atlantismo, co obxectivo de diferenciar Galicia de España e, por extensión, da cultura mediterránea, os homes de Nós empregaron a actividade tradutora como instrumento político de resistencia e de autoafirmación nacional. Neste contexto, o presente traballo pretende demostrar que a tradución do drama popular de Yeats The Land of Heart's Desire (1894), publicado en galego co título de $O$ pais da saudade en 1935, foi empregada, dende a escolla do texto ata as estratexias tradutivas, para amosar as características diferenciais da lingua e da cultura galegas co fin de reafirmar a existencia de Galicia como nación.
\end{abstract}

Palabras clave: tradución, identidade nacional, apropiación, celtismo, atlantismo, diferenciación cultural e lingüística.

\begin{abstract}
The translation of Irish literary texts into Galician during the Nós period (1916-1936) played a key role in the process of reconstruction of the national identity in Galicia. Following a political agenda based on the concepts of Atlantism and Celticism with the aim of differentiating Galicia from Spain and, by extension, from the Mediterranean culture, a group of intellectuals used translation as a political instrument of resistance and national self-affirmation. In this context, the following article focuses on the rendering of Yeats's folk drama The Land of Heart's Desire (1894), published in Galician with the title of $O$ pais da saudade in 1935. It intends to demonstrate that, from the selection of the text to the strategies applied by the translators, this translation was used to show the differentiating features of the Galician language and culture in order to reaffirm the existence of Galicia as a nation.
\end{abstract}

Key words: translation, national identity, appropriation, Celticism, Atlantism, cultural and linguistic differentiation. 


\section{TRADUCIÓN E RECUPERACIÓN DA IDENTIDADE NA ÉPOCA NÓS}

A tradución é un acto social e cultural que se encadra nunhas circunstancias políticas, sociais, históricas e culturais determinadas e, neste sentido, as modernas teorías de tradución poscolonial asóciana con procesos políticos como dominación, submisión, asimilación e resistencia (Robinson, 1997), tendo en conta as desigualdades existentes entre comunidades lingüísticas e desmitificando a idea de fidelidade ao texto orixe. Dende este punto de vista, a tradución deixa de ser unha actividade mimética que ten por obxectivo reproducir o orixinal e pode chegar a ser un proceso de apropiación, e mesmo de manipulación, que busca establecer un diálogo cultural co alleo, un proceso de comunicación bidireccional no que o tradutor participa de forma creativa na produción do texto meta (Vieira, 1999). Estes postulados teóricos resultan especialmente relevantes no contexto dunha cultura minorizada, onde a práctica da tradución pode converterse nunha forma de resistencia e o texto traducido «na representación simbólica da súa autoafirmación cultural e/ou nacional, da súa loita pola diferenciación cultural e/ou política.» (Millán Varela, 1998, p. 60). Este é o caso que atopamos en Galicia na época Nós, onde a tradución forma parte dun programa ideolóxico que se basea na diferenciación cultural e lingüística co obxectivo de recuperar a identidade nacional.

Para xustificaren a identidade diferencial de Galicia con relación ao resto do Estado español, os intelectuais galegos que formaban parte das Irmandades da Fala e da Xeración Nós no primeiro terzo do século XX recorreron ao hipotético pasado celta que fora introducido polos historiadores do XIX ${ }^{1}$. Fronte aos valores da cultura mediterránea, definida por Risco (1921, p.122) como «cultura allea, falsa e ruín, vulgar e filistea», propuñan o nacemento dunha civilización atlántica que pasaba «polo rexurdir das antigas nacións celtas, encarnación dos valores que habían rexenerar Europa» (Álvarez Lugrís, 2005, p. 68). Esta visión atlantista da nación galega, baseada no romanticismo das nacións celtas, permitíalles vincular Galicia ao norte de Europa, en contraposición á cultura mediterránea que eles consideraban intelectualista e decadente. Especialmente relevante é a atracción que profesaron por Irlanda, á que consideraban unha nación irmá tanto polo compartido pasado celta como polas semellanzas históricopolíticas que tiña con Galicia debido a súa situación periférica e colonial. Asemade, os innovadores modelos literarios irlandeses constituían un referente fundamental para levar a cabo a recuperación da literatura galega. Por todas estas razóns, a tradución de autores irlandeses xogou un papel fundamental na época. Por unha banda, formaba parte dun programa máis amplo que consistía en introducir en Galicia a cultura e a literatura europeas como forma de resistencia ao imperialismo castelán, para o cal era fundamental que os grandes autores europeos do momento estivesen en galego, tal como declara Risco (1920b, p.12) «Me non parece ben que teñamos que coñece-la Europa en libros i en traducións casteláns [...] Temos que poñel-a cultura europea en galego». Por outra banda, estas traducións servían para introducir novos modelos literarios e afianzar as li-

1 Véxase Verea y Aguiar (1838); Vicetto (1986 [1865]); Murguía (1979 [1888-1901]). 
gazóns con Irlanda para, deste xeito, reafirmar a diverxencia étnica e a identidade diferencial de Galicia.

Ademais, tendo en conta que o principal símbolo identitario e diferenciador dunha comunidade é a lingua, un dos obxectivos fundamentais da tradución nesta época era fortalecer o galego e normalizar o seu uso. Como suliña Anderson (2006, p. 133), «Much the most important thing about languages is its capacity for generating imagined communities, building in effect particular solidarities». Os intelectuais de Nós eran plenamente conscientes desta relación entre lingua e nación «Eisiste, pois un vencello antr'o idioma d'un pobo e a nación qu'o fala [...] a comunidade d'idioma abonda para fixar unha comunidade de cultura e unha comunidade de sentimentos» (Canedo, 1930, p.238). A lingua era, xa que logo, un elemento fundamental na loita pola reconstrución da nación galega, xa que «¿Qué poderá ser Galicia s'arrenega da sua alma, que é a sua lingua, donada por Dios, xenerada nos seos misteriosos da raza, recibida por nos en herdo dos nosos pais, dos nosos abós, dos nosos dinantepasados?» (Villar Ponte² ${ }^{2}$ 1917, p. 4).

Tendo en conta todas estas consideracións, neste artigo tratarei de amosar que a tradución de The Land of Heart's Desire foi empregada como un instrumento político de resistencia e de diferenciación cultural e lingüística, co obxectivo de recuperar a identidade nacional galega, baseada no concepto de enxebrismo, entendido como «a nosa orixinalidade específica, a nosa capacidá de creación, o noso autóctono dinamismo mental» (Nós, 1920a, p.2).

\section{CELTISMO E SAUDADE}

O poeta e dramaturgo nacionalista irlandés, William Butler Yeats (18651939), un dos iniciadores do rexurdimento literario en Irlanda, foi o autor máis traducido na época Nós. O grande interese que espertou nos intelectuais galegos debeuse a dous aspectos fundamentais, o seu Celtismo «Por il o Celtismo entrou na gran literatura» (Nós, 1920b, p.16) e o seu enxebrismo, que se reflexa na súa atracción polo popular e, polo tanto, na introdución do folklore tradicional irlandés nas súas obras. O seu drama popular, The Land of Heart's Desire (1894), foi traducido ao galego co título de $O$ pais da saudade por Plácido Castro e os irmáns Villar Ponte. Os tres tradutores eran membros das Irmandades da Fala e participaron activamente na recuperación do idioma galego así como no establecemento dos cimentos para a creación dun incipiente teatro, tomando como modelo o Irish Dramatic Movement ${ }^{3}$. A tradución publicouse en 1935 como par-

${ }^{2}$ Esta cita é parte dun discurso que aparece encabezado co apelido de Villar Ponte (sen nome), polo que o autor podería ser tanto Antón como o seu irmán Ramón.

${ }^{3}$ Movemento teatral formado por iniciativa de W.B. Yeats, Lady Augusta Gregory e Edward Martyn co obxectivo de crear un teatro nacional irlandés, con obras inspiradas na tradición irlandesa. O proxecto faise realidade en 1899 coa creación da compañía teatral Irish Literay Theatre, que se estrea coa representación da obra de Yeats, The Countess Cathleen. A compañía contou con directores como os dramaturgos Yeats e Synge e desenvolveu o xénero do folk-drama. Inicialmente, moitas das obras representadas recibiron críticas por ofrecer unha visión da realidade irlandesa que se afastaba dos estereotipos. Porén, pouco a pouco a compañía foi gañando a aceptación do públi- 
te dun volume titulado Dous folk-dramas de W.B.Yeats, que incluía tamén unha tradución de Cathleen ni Houlihan, cunha nota na portada anunciando que os dous folk dramas foran «vertidos â língoa galega direitamente do inglés por Plácido Castro e os irmáns Vilar Ponte, con licencia do autor».

A acción da obra está ambientada nunha casa labrega, a da familia Bruin, no condado de Sligo (Irlanda) na noite de May Evet (véspera do 1 de maio), onde a recén casada Mary Bruin mostra máis interese en ler contos populares sobre fadas ca en desempeñar as labores do fogar. Ante isto, os pais do seu home Shawn Bruin, Bridget e Maurteen, pídenlle axuda ao crego, Father Hart, que está na casa de visita, para disuadir á moza da súa lectura. Porén, aínda que lle advirten dos perigos desa noite na que as fadas teñen poderes inusuais sobre os mortais e poden levar con elas ás mulleres recén casadas para convertelas nas súas esposas, Mary, no canto de asustarse, séntese atraída pola idea de fuxir da súa rutina e das constantes críticas de Bridget e invita as fadas a que a leven. Unha fada nena entra na casa e cativa a moza mediante un ritual de canto e baile mentres que o resto da familia queda espavorecido. Ao final, Mary decide marchar coa fada e o seu corpo sen vida é o único que deixa na casa da familia Bruin.

Aínda que, a ollos nus, a obra non teña unha mensaxe política moi clara, pódese ver que os desexos de Mary de fuxir da súa opresiva realidade e cativerio son comparábeis aos desexos dos intelectuais galegos de escapar da presión e influencia castelás ${ }^{5}$. Da mesma maneira que Mary atopa a súa terra desexada polo corazón no mundo das fadas, é dicir, na tradición popular irlandesa, Galicia, seguindo o mesmo modelo, atoparía a nación libre e soñada «adentro de nós mesmos» (Risco, 1921, p.122) porque «era o sangue dos nosos antergos, dos ártabros fortes, dos feros brigantes, o que nos facía soñadores, románticos, lonjanos, individualistas» (p.123). Dende esta perspectiva, o drama popular de Yeats adquire un papel importante na difusión do mito celta en Galicia e a súa relevancia na creación dunha identidade nacional. É preciso facer mención especial á tradución do título que nun artigo publicado por Nós en 1920, «Letras Irlandesas. W.B. Yeats», se traduce como «A Terra do Deseo do Curazón» (p.16), mostrando fidelidade ao título orixinal de Yeats. Porén, os tradutores rexeitan esta solución e elixen $O$ pais da saudade como título da versión galega. Inclúese, polo tanto, a noción da saudade, que é unha das características definitorias da personalidade orixinal de Galicia. Plácido Castro analiza este concepto nunha serie de artigos publicados por El Pueblo Gallego en $1927^{6}$, onde explica que «La saudade, como el arte, es el producto de un deseo de algo, no sabemos bien de

co e acadou recoñecemento en toda Europa. En 1903 converteuse nunha compañía estable co nome de Irish National Theatre Society, e no ano seguinte, grazas ao favor de Annie Hornimann conseguiu un espazo fixo para as súas representacións, o Abbe Theatre.

${ }^{4}$ Segundo a tradición celta, na véspera do 1 de maio, xunto ca do 1 de novembro, desaparece a barreira entre o mundo humano e o sobrenatural. Nesta noite as bruxas e as fadas vagan libremente polo mundo dos mortais que deben tomar medidas para protexerse dos seus meigallos.

5 Hurtley (2006, p.83), referíndose a unha tradución da obra ao catalán de 1927, establece a mesma relación entre a temática do drama popular e as aspiracións nacionalistas de Cataluña.

6 'Saudade y Arte I'; 'Saudade y Arte II'; 'Saudade y Arte III'. Os tres artigos foron posteriormente recollidos nun folleto titulado El arte y la saudade en los pueblos célticos, editado por El Pueblo Gallego en 1928. 
qué, y es precisamente la vaguedad del anhelo lo que la distingue del sencillo deseo de volver a la patria y la eleva a la categoría de sentimiento artístico» (Castro, 1927a, p.2). Esta visión da saudade como concepto artístico é, para o humanista corcubionés, a inspiración esencial da arte celta, e neste sentido afirma que «Muchos poemas de los celtas del Norte podrían ser nuestros por la semejanza de los sentimientos que contienen» (Castro, 1927b, p.2). No mesmo traballo, Castro considera que hai dúas alternativas artísticas para Galicia: unha sería seguir a tradición popular «inspirándonos en la tradición, la leyenda y la saudade» (Castro, 1927b, p.2), e a outra «crear un arte frío, intelectual, que podría ser muy europeo pero que no tendrá contacto alguno con el espíritu de la raza» (Ibid.). Obviamente, tanto el como os seus contemporáneos decantáronse pola primeira opción que é a que se axustaba ao seu ideario político. Nestes comentarios así como na referencia que aparece no Agasallo do volume ao «orvallo celta da saudade, común a todol-os pobos da mesma raza» (Yeats, 1935, p.1), faise patente a asociación entre os conceptos de celtismo e saudade. Os tradutores atoparon a combinación dos dous no drama popular irlandés, a fórmula elexida por eles para renovar o teatro galego, evitando a imitación de modelos casteláns, porque como sinala A. Villar Ponte:

Los asuntos temáticos para nuestro teatro considero lógico buscarlos, como dijo muy bien P.R. Castro, en las tradiciones, leyendas y motivos autóctonos que perduran en la memoria de la raza y guardan afinidad con los de otros pueblos hermanos, por cuyas venas corre sangre celta. A base de ellos y siguiendo procedimientos análogos en su desenvolvimiento a los del teatro irlandés, verbigracia, daremos con nuestro módulo original (Villar Ponte, 1927, p.1).

Outro aspecto que non debe pasar desapercibido é a tradución de land por «país», que podería ser entendido como nación, e deste xeito, tal como apunta Hurtley (2006, p.89) representaría a reivindicación das esperanzas nacionalistas, en relación coa saudade dunha nación libre de influencias imperialistas, xa que, segundo Castro, Galicia precisaba «la saudade de una nueva Galicia, que sea como en Irlanda el distante ideal que al fin nos lleve a una feliz realidad». (Castro, 1927c, p.2).

Queda claro, xa que logo, que, dende o mesmo título, a tradución se manifesta como un proceso de manipulación levado a cabo cun obxectivo político claro, que non é outro que reafirmar a identidade diferencial de Galicia mediante a súa afiliación ás nacións celtas do norte de Europa.

\section{ESTRATEXIAS DE TRADUCIÓN}

De entre as cinco estratexias que Bassnett (1985, pp.90-91) propón para a tradución de textos teatrais, Plácido Castro e os irmáns Villar Ponte aplican a que a autora denomina translating performability, que consiste en crear un texto que sexa transparente na lingua meta e implica que a fidelidade se sacrifica frecuentemente para que a tradución se adapte ao contexto da mesma. Un primeiro 
exemplo desta técnica maniféstase na decisión de traducir a obra, orixinalmente escrita en verso libre por Yeats, en prosa, que se pode interpretar como unha maneira de facilitarlle a lectura a un público que estaría máis familiarizado coa lectura de novelas ca de teatro, e menos teatro en verso. Esta decisión de tradución sería, xa que logo, «a reflection of target language norms and the preferences of a particular community at a particular point in time» (Baker, 1998, p.174).

A estratexia xeral que empregan os tradutores podémola definir como «galicianización» do texto de partida para facelo máis autóctono e afastarse de semellanzas co castelán, polo tanto hai unha énfase en estratexias de diferenciación lingüística, o cal evidencia o uso da tradución como instrumento político. A continuación ofrécese unha análise das distintas estratexias tradutivas empregadas, que se poden clasificar nas seguintes categorías: diferenciación lingüística, supresión/retención de elementos foráneos, adicións, omisións.

\subsection{Diferenciación Lingüística}

\subsubsection{Léxico}

A nivel léxico, téndese a reproducir o significado do orixinal evitando en todo momento a coincidencia ou analoxía co castelán mediante o uso de formas máis «puramente» galegas. Esta é a estratexia que Millán Varela (1997, p.288) na súa análise da tradución dos fragmentos do Ulysses chama «achegamento ao significado do texto de partida», e que se ilustra no apéndice.

En todos os exemplos incluídos na táboa (véxase apéndice), os tradutores reproducen o significado do texto orixe escollendo solucións galegas que sexan o máis diferentes posíbel do castelán. Ás veces esta busca da diferenza lévaos a empregar palabras que teñen un significado máis específico ca o termo que aparece no orixinal. Por exemplo, «tallo» emprégase tanto para traducir bench como seat e «labarada» para traducir light en referencia a luz producida polo lume. Outro efecto importante desta estratexia é que, a miúdo, o propósito da diferenciación lingüística leva os tradutores a engadir máis variedade de vocabulario da que existe no texto orixe, como podemos ver nos seguintes casos: to dress traducido como «adobiados» e «enfeitados», to hang traducido como «dependurar»e «pendurar» e to cross para o que utilizan o verbo «arruzar» e o nome «cabuxo», aínda que o verbo «encabuxar» tamén é empregado para traducir to vex, rebaixando o rexistro do texto. Ao faceren isto, os tradutores explotan a riqueza léxica da lingua galega como se pode observar tamén na tradución de coaxing ways por tres adxectivos diferentes: «lizgaira», «feituca», «solermeira». Esta solución non só engade información que non está no orixinal, senón que ademais contribúe a incrementar os efectos líricos do texto. Nalgúns casos un nome concreto é empregado no canto dun nome abstracto, por exemplo «casás» por hearths. Especialmente relevante é o caso da tradución de something por «lilaina» cando Marteen lle ofrece uns lazos á fada nena, xa que con esta tradución non só se evita a coincidencia co castelán, senón que tamén se inclúe unha referencia cultural, xa que «lilaina» aparece nunha cantiga popular galega: 


\section{Todos me andan preguntando \\ de que romería veño. \\ Veño da Santa Lilaina, \\ da Santa Lilaina veño. ${ }^{7}$}

Debe facerse unha mención especial ao uso do sufixo -bel en amábel. Actualmente, as dúas solucións -bel e -ble están aceptadas para os adxectivos rematados no sufixo derivado do latín -BILIS (Feixó Cid, 2005, p. 48), aínda que a forma máis estendida na lingua falada sempre foi -ble que coincide coa forma en castelán. Porén, a importante presenza de -bel na lingua escrita dende o século XIX tomouse como criterio para incluír esta forma na normativa oficial ${ }^{8}$. Isto é un exemplo de como os esforzos dos tradutores, así como doutros intelectuais e autores da época, por transformaren o galego nunha lingua diferenciada, sobreviviron no tempo. O caso de - $b e l$ non é o único no que os tradutores empregan sufixos «puramente» galegos con afán de diferenciación, como mostra o uso de «encollidiña» para traducir you're crouching. De feito, o uso do sufixo -iño, un dos signos de identidade máis importantes da lingua galega, é prolífico en todo o texto, como se amosa na seguinte táboa:

\begin{tabular}{|l|l|}
\hline \multicolumn{1}{|c|}{ Texto orixe } & \multicolumn{1}{c|}{ Texto meta } \\
\hline double over it (p.181) & dobregadiña encol del (p.19) \\
\hline quiet (p.182) & acougadiña (p.19) \\
\hline woe (p.189) & Disgraciadiña (p.22) \\
\hline house (p.191) & casiña (p.23) \\
\hline wet (p.196) & molladiño (p.25) \\
\hline beloved (p.208) & meu amoriño (p.29) \\
\hline face (p.208) & cariña (p.29) \\
\hline
\end{tabular}

Os exemplos presentados dan mostra dos esforzos por empregar unha lingua que estivese libre de influencias casteláns para poder ser recoñecida como un idioma en si mesmo e un símbolo dunha nación diferenciada. Este era, sen dúbida, o obxectivo principal que pretendían acadar coa tradución, e por iso hai veces nas que a estratexia de diferenciación lingüística os leva a desviacións semánticas do texto de partida, como se pode ver na táboa que segue:

7 A cantiga aparece nunha das definicións de «lilaina» en Rodríguez González (1958-1961).

${ }^{8}$ Para máis información sobre a evolución das normas oficiais do galego, véxase Muñoz Carrobles (2008, pp. 49-56). 


\begin{tabular}{|l|l|}
\hline \multicolumn{1}{|c|}{ Texto orixe } & \multicolumn{1}{c|}{ Texto meta } \\
\hline 1. one can see the forest (p.180) & fítase o bosco (p.19) \\
\hline 2. $[\ldots]$ knock upon our doors (p.188) & $\begin{array}{l}{[\ldots .] \text { petan nas pobres portelas dos nosos }} \\
\text { fogares (p.22) }\end{array}$ \\
\hline 3. all kinds of evil (p.192) & soma desavegosa (p.23) \\
\hline 4. looks (p.193) & fitando (p.24) \\
\hline 5. to see (p.193) / sees (p.198) & para fitar (p.24) /fita (p.26) \\
\hline 6. $[\ldots]$ my hair grows thin (p.203) & {$[.$.$] meus cabelos caen a feito [...] (p.27)$} \\
\hline 7. light (p.208) & lizgairas (p.29) \\
\hline
\end{tabular}

Nos exemplos 1, 4 e 5, emprégase «fitar» para traducir to see e to look, aínda que introduce un pequeno cambio de significado, afástase de solucións que coincidirían co castelán como «ver» ou «mirar». No segundo caso, os tradutores elixiron a palabra galega «portelas» para evitar a semellanza co castelán mediante o uso de «portas», aínda que esta solución supón un cambio de significado, xa que «portela» se refire a unha cancela que permite o paso do gando nunha leira pechada. No terceiro exemplo, nunha pasaxe que fai referencia á desgraza que caerá na casa da familia Bruin porque Mary ofendeu ás fadas, os tradutores rexeitan a tradución literal «todo tipo de maldades», que sería case coincidente co castelán e optan por unha solución máis galega, «soma desavegosa», na que «soma» é unha variante de «sombra». Esta solución fai referencia ao significado simbólico desta palabra na tradición literaria galega por mor do famoso poema de Rosalía de Castro «Negra Sombra», no que a «sombra» se identifica con mágoa e sufrimento. Non sería, xa que logo, desacertado pensar que serviu de inspiración para esta decisión de tradución. Aínda que difire lixeiramente do texto de partida, dálles aos tradutores a oportunidade de incluír unha referencia á tradición literaria galega. No exemplo 6, mentres que no texto orixe o pelo da nena se debilita, na tradución pérdeo completamente para os tradutores poderen empregar a expresión galega «caer a feito». Para rematar, no último exemplo o adxectivo light que se refire a lixeireza das fadas que poden montar os ventos e bailar enriba das montañas, é traducido pola palabra xenuinamente galega «lizgairas», co consecuente cambio de significado, pero afástase dunha solución que sería moi semellante ao castelán: «lixeiras».

Nalgúns casos o propósito de diferenciación lingüística leva tamén ao uso dalgunhas palabras que non existen en galego. Un caso curioso é o emprego de «gaudir» co significado de «comer» no seguinte exemplo, «(But supper's spre$\mathrm{ad}$, and we can talk and eat.)»(p.183)/ «(Pro está servida a cea e poderemos darll'a lingua mais e millor, entramentras gaudimos.)» (p.20). Este verbo non existe no galego actual e tampouco foi atopado como tal en ningún dos dicionarios, glosarios e documentos da época que foron consultados, polo tanto é unha solución de tradución que produce certa estrañeza. Porén, si que está re- 
xistrada a existencia do substantivo «gaudio» ${ }^{9}$ co significado de «gozo, ledicia», polo que poderiamos dicir que o verbo «gaudir» é unha creación léxica que parte dun termo xa existente na lingua respectando as normas morfolóxicas do galego. Neste caso, o termo faría referencia ao goce producido pola comida que están a punto de inxerir, nun claro intento de evitar o uso de «comer» ou «cear» e, por conseguinte, coincidencia/semellanza co castelán. Aínda que o verbo «gaudir» existe en catalán co mesmo significado de «gozar», en ningún caso se debe entender o emprego deste verbo na versión galega como se fose unha solución baseada na tradución do drama popular ao catalán que La Revista publicou en 1927, xa que a solución que o tradutor catalán, Mariá Manent, emprega neste caso é: Però sopem; ja parlarem, a taula (Yeats, 1927, p.126). Outro exemplo semellante de utilización dunha palabra que non aparece en ningún dos dicionarios e glosarios consultados é o verbo «abeñoar» en: «That blinks and blinks [the Eagle-cock]»(p.203)/ [...] «que abeñoa a voar senlleira» (p.28). De novo, si que está documentada a existencia do substantivo «abéñoa» ${ }^{10}$ coa variante «avéñoa» (pálpebra), polo que cabe dicir que aquí entenderon blink como «palpebrexar» e crearon o verbo «abeñoar» a partir dun substantivo existente, o que, por outro lado, evita unha solución que sería análoga ao castelán: «axitar as ás». Este tipo de creacións léxicas eran frecuentes na época Nós e estaban xustificadas para transformar o galego nunha lingua diferenciada ${ }^{11}$.

Outro aspecto que cómpre destacar é a énfase na fonoloxía para facer que o drama popular soe máis autóctono ao reproducir trazos da lingua falada para cumplir o imperativo ideolóxico de converter o galego, que naquel tempo era unha lingua degradada e principalmente reducida ao uso das clases rurais, nunha lingua de prestixio apta para presentar a literatura europea máis innovadora. Por iso, non é estraño que unha serie de fenómenos fonolóxicos aparezan reflectidos ao longo do texto, como se mostra de seguido coas solucións que se aceptan no galego moderno entre corchetes.

Paragoxe: traballare (p.19) [traballar], remendare (p.19) [remendar], cabalgare (p.19) [cabalgar], termare (p.20) [termar], poñere (p.20) [poner], sofrire (p.20) [sufrir], escribire (p.20) [escribir], sabere (p.20) [saber], bailare (p.20) [bailar], dare (p.20) [dar], traguere (p.21) [traer], abranguere (p.21) [abranguer], señore (p.21) [señor], tere (p.21) [ter], sere (p.23) [ser], traguere (p.25) [traer], beilare (p.26, p.27) [bailar].

Epéntese: da i-auga (p.20) [da auga], meio (p.20) [medio], ceios (p.20) [ceos], a i-auga (p.21) [a auga], poseia (p.22) [posea], sua i-alma (p.28) [súa alma].

Síncope: arbres (p.19) [árbores], arbre (p.19) [árbore], aspro (p.23) [áspero].

Aférese: inda (p.28) [aínda].

9 Véxase Cuveiro Piñol (1876) e Filgueira Valverde, Tobío Fernandez, Margariños Negreira e Cordal Carús (1926).

10 Véxase Filgueira Valverde, Tobío Fernandez, Magariños Negreira e Cordal Carús (1926).

11 Véxase por exemplo Portela Valladares (1923). 
Apócope: calquer (p.20) [calquera], crás (p.22) [crase], quer (p.26) [quere].

Metátese: perciso (p.24) [preciso], probes (p.26) [pobres]

Apóstrofo: desd'entón (p.19) [desde entón], d'el (p.19) [del] (p.19), n’hai (p.19) [non hai], d'aquel (p.20) [daquel], d'anos (p.20) [de anos], d'o (p.20) [do], d'ese (p.20) [deses], d'el (p.20) [del], d'un (p.20) [dun], d'Irlanda (p.20) [de Irlanda], n'unha (p.20) [nunha], d'hoxe (p.20) [de hoxe], Ond'é (p.20) [Onde é] s'encha (p.20) [se encha], d'orgullo (p.20) [de orgullo], m'eu (p.21) [meu], d'eu (p.21) [deu], c'o (p.22) [co], d'ele (p.22) [del], ch'eu (p.27) [che eu], c'os (p.27) [cós].

A tradución mostra tamén a falta de unificación da lingua na época, que se reflexa na utilización de variedades dialectais. Aparecen algúns fenómenos lingüísticos propios do bloque occidental como seseo nas palabras «vellés» (p.21) e «coraçón» (p.20, p.24) e terminación verbal —is para a segunda persoa do plural do presente de indicativo: «tomeis» (p.28), «abandoneis» (p.29) (este fenómeno tamén ocorre no bloque central). Atópanse tamén outros trazos lingüísticos que caracterizan ao bloque central como a terminación —ao en «chao» (p.19) no canto de «chan» e a intersección de -ñ- entre dúas vogais no presente de subxuntivo de certos verbos: «seña» (p.21), «esteña» (p.22, p.25).

\subsubsection{Sintaxe}

As estratexias de diferenciación lingüística non afectan unicamente ao léxico senón tamén a sintaxe do texto posto que os tradutores, a miúdo, fan cambios nas estruturas gramaticais para incluír estruturas, vocabulario e expresións máis xenuinamente galegas. O efecto xeral desta estratexia é que o drama popular adquire un carácter máis vernáculo aínda que para isto, ás veces, se empreguen determinadas solucións lingüísticas que resultarían pouco idiomáticas. A tradución convértese, desta maneira, nun forte instrumento de desalienación que pretende darlle á lingua galega o estatus que durante tanto tempo lle fora negado. De seguido, preséntase uns exemplos das principais estratexias tradutivas aplicadas no nivel sintáctico divididas en diferentes grupos, segundo o trazo lingüístico que os tradutores pretenden reforzar en cada caso: infinitivo conxugado, pronomes, vocabulario e expresións tipicamente galegos.

\subsubsection{Cambios sintácticos para empregar o infinitivo conxugado}

Os casos nos que os tradutores cambian a estrutura gramatical do texto orixe para poder empregar o infinitivo conxugado, unha forma verbal xenuinamente galega que non existe en castelán, son numerosos ao longo do texto, polo tanto presentaranse só algúns exemplos representativos: 


\begin{tabular}{|c|c|}
\hline Texto orixe & Texto meta \\
\hline $\begin{array}{l}\text { 1. Colleen, what is the wonder in that } \\
\text { book, } \\
\text { That you must leave the bread to cool? } \\
\text { (p.183) }\end{array}$ & $\begin{array}{l}\text { ¡Ei, rapaza! ¿qué maravillas choe ise libro } \\
\text { para ti deixares enfrial-o pan? (p.20) }\end{array}$ \\
\hline $\begin{array}{l}\text { 2. And then come the wrecked angels and } \\
\text { set snares, }[\ldots] \text { (p.184) }\end{array}$ & $\begin{array}{l}\text { Logo veñen os anxos náufragos a poñe- } \\
\text { ren engados e tentacións [...] (p.20) }\end{array}$ \\
\hline $\begin{array}{l}\text { 3. [...] but years went by } \\
\text { And they grew like their neighbours } \\
\text { and were glad } \\
\text { In minding children, working at the } \\
\text { churn, } \\
\text { And gossiping of weddings and of wa- }\end{array}$ & $\begin{array}{l}\text { kes; (p.185) } \\
\text { [...] mais ô pasaren os anos e voltárense } \\
\text { com'as suas veciñas, sintiron de novo o } \\
\text { lecer de coidal-os seus meniños, de fa- } \\
\text { gueren a manteiga, de latricaren de ca- } \\
\text { soiros e romaxes; (p.21) }\end{array}$ \\
\hline $\begin{array}{l}\text { 4. That women hung upon the post of the } \\
\text { door } \\
\text { That they may send good luck into the } \\
\text { house? } \\
\text { Remember they may steal new married } \\
\text { brides (p.186) }\end{array}$ & $\begin{array}{l}{[\ldots] \text { que as mulleres penduran do limiar }} \\
\text { da porta para fagueren que a boa sorte } \\
\text { nos entre na casa. Lémbrate ben de que } \\
\text { poden roubaren as casadas de pouco tem- } \\
\text { po [...] (p.21) }\end{array}$ \\
\hline $\begin{array}{l}\text { 5. Maurteen. Come, sit beside me, colle- } \\
\text { en, }[\ldots] \text { (p.189) }\end{array}$ & $\begin{array}{l}\text { MART. A Maruxa. Ven a te sentares ei- } \\
\text { quí, acarón de min, rapaza; (p.22) }\end{array}$ \\
\hline $\begin{array}{l}\text { 6. Before you married you were idle and } \\
\text { fine } \\
\text { And went about with ribbons on your } \\
\text { head; (p.191) }\end{array}$ & $\begin{array}{l}\text { Antes de te casares eras folgazana e nu- } \\
\text { gallona, inda que esguía e xeitosa, e gos- } \\
\text { tabas de te por galanos adovíos nos ca- } \\
\text { belos; (p.23) }\end{array}$ \\
\hline $\begin{array}{l}\text { 7. Mary. Come, faeries, take me out of } \\
\text { this dull house! (p.191) }\end{array}$ & $\begin{array}{l}\text { MARUXA - ¡Vinde fadas, vinde axiña a } \\
\text { me leváredes d'esta casa triste! (p.23) }\end{array}$ \\
\hline $\begin{array}{l}\text { 8. [...] and must be tired and hungry. } \\
\text { (p.196) }\end{array}$ & $\begin{array}{l}{[\ldots] \text { tes que estares cansa e sentires moi- }} \\
\text { ta fame. }(\text { p. } 25)\end{array}$ \\
\hline $\begin{array}{l}\text { 9. Shawn [raising]. Though you have } \\
\text { made all these obedient (p.204) }\end{array}$ & $\begin{array}{l}\text { XOAN (Erguíndose). Inda que teñas feito } \\
\text { obedeceres a todos estes (p.28) }\end{array}$ \\
\hline $\begin{array}{l}\text { 10. The Child. You shall go with me }[\ldots] \\
\text { And gaze }[\ldots](\text { p.205) }\end{array}$ & $\begin{array}{l}\text { A NENA }[\ldots] \text { Virás cand'a min }[\ldots] \text { a } \\
\text { ollares }[\ldots] \text { (p.28) }\end{array}$ \\
\hline $\begin{array}{l}\text { 11. Nor all the faery host }[\ldots] \\
\text { Shall ever make me loose you from } \\
\text { these arms. (p.208) }\end{array}$ & $\begin{array}{l}{[\ldots] \text { e nen todal-as hostes das fadas }[\ldots]} \\
\text { han poder conseguiren que te ceibes das } \\
\text { miñas mans. (p.29) }\end{array}$ \\
\hline
\end{tabular}

Como se pode ver nestes exemplos, o infinitivo conxugado emprégase frecuentemente en construcións perifrásticas $(2,5,8,9,10)$, dando como resultado estruturas que resultan pouco idiomáticas, xa que este tipo de construcións son un dos casos que se resisten ao uso desta forma verbal. Asemade, o seu uso despois do verbo modal «poder» (4-segundo infinitivo-, 11) produce un efecto que resulta bastante artificial. Esta utilización excesiva do infinitivo conxugado, 
mesmo en contextos nos que non sería correcto, é unha estratexia de diferenciación lingüística extrema que se encadra dentro do ideario político dos tradutores. Non só crean un texto novo senón que tamén crean unha lingua ao facer o galego máis enxebre para reafirmar a súa existencia como idioma en si mesmo.

\subsubsection{Cambios sintácticos para empregar usos pronominais xenuinamente galegos}

Nos exemplos anteriores pódese apreciar o uso doutro trazo lingüístico característico e distintivo do galego, como é a inclusión dun pronome entre unha preposición e un infinitivo $(1,5,6,7)$, que tamén se pode observar nos exemplos seguintes:

\begin{tabular}{|l|l|}
\hline \multicolumn{1}{|c|}{ Texto orixe } & \multicolumn{1}{c|}{ Texto meta } \\
\hline $\begin{array}{l}\text { There is one here that must away, away. } \\
\text { (p.196) }\end{array}$ & $\begin{array}{l}{[\ldots] \text { unha hai eiquí que ten de se ire, de }} \\
\text { se marchare ... (p.25) }\end{array}$ \\
\hline $\begin{array}{l}\text { I will instruct you in our blessed Faith; } \\
\text { (p.200) }\end{array}$ & $\begin{array}{l}{[\ldots] \text { haberei de te instruire na nosa santa }} \\
\text { fé; (p.26) }\end{array}$ \\
\hline
\end{tabular}

Noutros casos os tradutores fan as modificacións necesarias na estrutura oracional para poder incluír o pronome de solidariedade, outro trazo definitorio do galego que non existe en castelán:

\begin{tabular}{|l|l|}
\hline \multicolumn{1}{|c|}{ Texto orixe } & \multicolumn{1}{c|}{ Texto meta } \\
\hline$[\ldots .$.$] She must be one of them. (p.189)$ & $\begin{array}{l}{[\ldots] \text { ben che podería sere d'aquela xente. }} \\
(\mathrm{p} .22)\end{array}$ \\
\hline The Child. I am welcome here. (p.195) & A NENA - Sonche benvida [...] (p.25) \\
\hline The Child. No more, mother. (p.198) & $\begin{array}{l}\text { A NENA - Non lle quero mais, ña nai. } \\
\text { (p.26) }\end{array}$ \\
\hline $\begin{array}{l}\text { The Child. You love that young man the- } \\
\text { re (p.202) }\end{array}$ & $\begin{array}{l}\text { A NENA -Quéreslle ti a ese mozo mo- } \\
\text { ciño ... (p.27) }\end{array}$ \\
\hline
\end{tabular}

3.1.2.3. Cambios sintácticos para incluír vocabulario e expresións «puramente» galegas.

A miúdo os tradutores fan cambios nas estruturas sintácticas do texto orixe que lles permiten incluír vocabulario e expresións «puramente» galegas, que polo tanto, se afastan considerablemente do castelán: 


\begin{tabular}{|l|l|}
\hline \multicolumn{1}{|c|}{ Texto orixe } & \multicolumn{1}{|c|}{ Texto meta } \\
\hline $\begin{array}{l}\text { We do not know the limit of those po- } \\
\text { wers (p.186) }\end{array}$ & $\begin{array}{l}\text { Non chegamos a abranguere nunca en } \\
\text { ningures o límite dos poderes [...] (p.21) }\end{array}$ \\
\hline
\end{tabular}

Neste caso rexéitase a tradución literal «Non sabemos o límite deses poderes» pola súa semellanza co castelán, e o cambio na estrutura da oración permítelles aos tradutores empregar vocabulario máis autóctono como «abranguere»e «ningures».

\begin{tabular}{|l|l|}
\hline \multicolumn{1}{|c|}{ Texto orixe } & \multicolumn{1}{c|}{ Texto meta } \\
\hline $\begin{array}{l}{[\ldots], \text { so it may be }} \\
\text { That she is thirsty. }(\mathrm{p} .188)\end{array}$ & $\begin{array}{l}{[\ldots] \text { cecais para que nos decatemos de }} \\
\text { que esliga de sede. }(\mathrm{p} .22)\end{array}$ \\
\hline
\end{tabular}

De novo, a tradución esperable que podería ser algo como «se cadra ten sede» é rexeitada, os tradutores engaden máis complexidade gramatical á estrutura, o que ao mesmo tempo lles da a posibilidade de empregar o verbo «decatar» e a expresión autóctona «esligar de sede».

\begin{tabular}{|l|l|}
\hline \multicolumn{1}{|c|}{ Texto orixe } & \multicolumn{1}{c|}{ Texto meta } \\
\hline You are much too cross. (p.191) & Encabúxaste d'abondo. (p.23) \\
\hline$[\ldots]$ — these are too old (p.192) & {$[\ldots]$ Eles son vellos d'abondo (p.24) } \\
\hline
\end{tabular}

Ao longo do texto, os tradutores galeguizan as estruturas que conteñen o cuantificador inglés too, traducíndoo por «d'abondo» e, deste xeito, evitan solucións que serían parecidas ao castelán como «moi» ou «moito».

\begin{tabular}{|l|l|}
\hline \multicolumn{1}{|c|}{ Texto orixe } & \multicolumn{1}{|c|}{ Texto meta } \\
\hline $\begin{array}{l}\text { [... So I will bring her in out of the cold. } \\
\text { (p.195) }\end{array}$ & $\begin{array}{l}\text { Vou traguere â nena que canta para que } \\
\text { perto da lareira escurrente o frío. } \\
\text { (p.25) }\end{array}$ \\
\hline
\end{tabular}

Neste exemplo o cambio de estrutura oracional permite, ademais do uso dun verbo xenuinamente galego «escurrentar», a introdución dun elemento cultural tradicional de Galicia, «lareira», que é unha importante estratexia de apropiación cultural, xa que transmite a idea de que a escena ten lugar en Galicia no canto de en Irlanda.

\begin{tabular}{|l|l|}
\hline \multicolumn{1}{|c|}{ Texto orixe } & \multicolumn{1}{|c|}{ Texto meta } \\
\hline $\begin{array}{l}\text { [...] reading a book. If she looks up she } \\
\text { can see through the door into the wood. } \\
\text { (p.181) }\end{array}$ & $\begin{array}{l}\text { [...]lendo nun libro, de xeito que, d'a- } \\
\text { rredare os ollos d'este, pode fital-o bos- } \\
\text { co. (p.19) }\end{array}$ \\
\hline
\end{tabular}


Aquí pódese ver como os tradutores combinan dúas frases por medio do conector modal «de xeito que» que difire substancialmente do seu homólogo castelán «de manera que». Por outra banda, inclúen un trazo sintáctico tipicamente galego que consiste en introducir os obxectos directos de verbos eventivos mediante a preposición «en» («ler nun libro»).

\begin{tabular}{|l|l|}
\hline \multicolumn{1}{|c|}{ Texto orixe } & \multicolumn{1}{|c|}{ Texto meta } \\
\hline $\begin{array}{l}\mid \ldots . .] \text { the moon or the late sunset glim- } \\
\text { mers through the trees }[. .](\mathrm{p} .180)\end{array}$ & $\begin{array}{l}\text { A lúa escomenza a peneiral-a foula de } \\
\text { prata por entremedias das arbres }[\ldots] \\
\text { (p.19) }\end{array}$ \\
\hline
\end{tabular}

Finalmente, podemos ver neste exemplo un caso de desviación completa do texto de partida, no que os tradutores empregan a súa imaxinación para crear unha metáfora diferente no texto meta. Para crear a nova imaxe recorren a unha actividade tradicional galega, peneirar a fariña, que lles permite empregar vocabulario autóctono como «peneirar»e «foula». Este exemplo amósanos ata que punto a tradución é unha actividade creativa que vai moito máis alá da reiteración do texto de partida.

\section{SUPRESIÓN/ RETENCIÓN DE ELEMENTOS FORÁNEOS}

Canto á supresión/rentención de elementos foráneos, os tradutores aplican unha estratexia domesticadora que implica a adaptación do texto ao contexto da lingua meta, evitando a reprodución de referencias culturais específicas do contexto da lingua orixe. Deste xeito termos como kettle (p.182) e porringer (p.197), convértense en «caldeira da i-auga» (p.20) e «cunca» (p.26), ámbolos dous utensilios que serían coñecidos para os receptores galegos. Na mesma liña, acres (p.190) pasa a ser «ferrados» (p.22), unha unidade de medida tipicamente galega e yellow guineas (p.189) aparece como «onzas marelas» (p.22), evitando a referencia a unha moeda estranxeira. Amais disto, tamén é notable que interpolan referencias culturais autóctonas como «lareira» (p.19, p.22), utilizada para traducir tanto hearth (180) como turf (p.189), e «cunca» que se usa na frase «Pilla unha cunca de leite» (p.22) para traducir she takes milk (p.188), onde se pode apreciar que no texto orixe non hai referencia ningunha a tipos de recipiente.

Outro exemplo importante de adaptación cultural é a tradución de evil upon the house (p.191) como «desdita do mal d'ollo para a nosa casiña» (p.23). Isto forma parte dun fragmento no que Bridget lle reprocha a Mary que lle dese leite e lume ás fadas atraendo, desta maneira, a desventura para a súa casa. Os tradutores aproveitan esta oportunidade para introducir un importante elemento de superstición en Galicia: o mal de ollo.

Hai tamén unha tendencia no texto a galeguizar nomes propios e, deste xeito, os nomes dos personaxes do drama popular preséntanse con nomes galegos: Marteen Bruin, Bridget Bruin, Shawn Bruin, Mary Bruin, e Father Hart convértense en Martiño Bruin, Bríxida Bruin, Xoán Bruin, Maruxa Bruin e P. Hart. A 
tradución de Mary por Maruxa no canto de María evita a coindicencia co castelán, da mesma maneira que o feito de que na tradución de Father Hart só apareza a inicial P. antes do apelido evita tamén a coincidencia ao non usar $\mathrm{Pa}$ dre ou Pater que serían as formas habituais de dirixirse ao crego na época. Porén, a estratexia de galeguización só afecta aos nomes e non aos apelidos que quedan como Bruin e Hart, mantendo así un elemento extranxeirizante que tamén se reflexa na retención dos topónimos en inglés: Ocris Head (p.183), Coolaney lake (p.198), Colver Hill (p.189) and Ballygawley Hill (p.203) son traducidos como Ocris Head (p.20), o lago de Coolaney (p.26) o monte do Clover (p.22) e o monte de Ballygawley (p.28).

En xeral, as referencias culturais son domesticadas na versión galega aínda que, como se acaba de comentar, mantéñense algúns elementos extranxeirizantes, polo tanto pódese afirmar que se produce un efecto de hibridación no texto traducido, é dicir, un proceso de identificación entre Irlanda e Galicia que se converten nun mesmo espazo simbólico. Os tradutores rompen a xerarquía entre texto orixe e texto meta ao non someterse ao primeiro e incluir referencias culturais específicas da cultura meta, desta maneira crean diferentes capas lingüístico-culturais (Mehrez, 1992, p.121) no texto traducido.

\section{ADICIÓNS}

A utilización de adicións é un recurso frecuente ao longo de todo o texto manifestando, de novo, que os tradutores empregan a súa creatividade e non se someten a xerarquía do texto de partida. As múltiplas adicións que aparecen na tradución crean diferentes efectos tal e como se explica a continuación:

\subsection{Adición de referencias relixiosas}

\begin{tabular}{|l|l|}
\hline \multicolumn{1}{|c|}{ Texto orixe } & \multicolumn{1}{c|}{ Texto meta } \\
\hline $\begin{array}{l}\text { It was little good he got out of the book, } \\
{[\ldots] \text { (p.183) }}\end{array}$ & $\begin{array}{l}\text { Non tirou gran proveito d'ese libro, asin } \\
\text { Deus me salve, o pai do meu pai, [...] } \\
\text { (p.20) }\end{array}$ \\
\hline $\begin{array}{l}\text { Maurteen. Persuade the colleen to put } \\
\text { down the book; (p.184) }\end{array}$ & $\begin{array}{l}\text { Mart. ao P. Hart. Deus que me deu. Ter- } \\
\text { me da rapaza para que deixe o libro. } \\
\text { (p.20) }\end{array}$ \\
\hline $\begin{array}{l}\text { My colleen, I have seen some other girls } \\
{[\ldots] \text { (p.185) }}\end{array}$ & $\begin{array}{l}\text { Na filla n'El Señor! Eu xa vin outras ra- } \\
\text { pazas [...] (p.21) }\end{array}$ \\
\hline $\begin{array}{l}\text { Bridget. She's old enough to know that it } \\
\text { is wrong } \\
\text { To mope and idle. (p.185) }\end{array}$ & $\begin{array}{l}\text { BRÍXIDA -É d'abondo vella para sa- } \\
\text { bere que en pecado s'atopa a que anda a } \\
\text { folganear iludida. (p.21) }\end{array}$ \\
\hline $\begin{array}{l}\text { We have a hundred acres of good land } \\
\text { (p.190) }\end{array}$ & $\begin{array}{l}\text { Temos, gracias al Señor, un cento de fe- } \\
\text { rrados de boas terras (p.22) }\end{array}$ \\
\hline $\begin{array}{l}{[\ldots] \text { Where I must hear all day a bitter }} \\
\text { tongue (p.191) }\end{array}$ & $\begin{array}{l}\text { [...] onde teño que ouvire tod'o día del } \\
\text { Señor una lingua aceda (p.23) }\end{array}$ \\
\hline
\end{tabular}


En todos os exemplos anteriores, os tradutores inclúen referencias relixiosas que non están motivadas polo texto orixe. Por unha banda, estas referencias, expresións de uso común na época, mesmo as que aparecen en castelán (El Señor, gracias al Señor), salientan a relixiosidade dos personaxes e por outra, relaciónanse co tipo de nacionalismo que os tradutores propugnaban, un nacionalismo que promocionaba valores católicos. Non obstante, hai que ter en conta que non só engaden alusións ao cristianismo no texto, senón que tamén enfatizan numerosas referencias aos poderes sobrenaturais pagáns, como amosan os exemplos seguintes:

\begin{tabular}{|c|c|}
\hline Texto orixe & Texto meta \\
\hline $\begin{array}{l}\text { 1. [An arm comes round the door-post } \\
{[\ldots](\mathrm{p} .188)}\end{array}$ & Un brazo vello, achacio, $[\ldots]$ (p.22) \\
\hline $\begin{array}{l}\text { 2. Mary. A little queer old woman dres- } \\
\text { sed in green. (p.188) }\end{array}$ & $\begin{array}{l}\text { MARUXA - Unha vella velliña, } \\
\text { com'outra non vin en ningures toda en- } \\
\text { feitada de verde. (p.22) }\end{array}$ \\
\hline $\begin{array}{l}\text { 3. Mary. Both the tongue and face were } \\
\text { strange. (p.189) }\end{array}$ & $\begin{array}{l}\text { MARUXA - Tanto a sua fala com'a sua } \\
\text { face parecéronme estranas, moi estra- } \\
\text { nas. (p.22) }\end{array}$ \\
\hline 4. Mary. A little queer old man. (p.191) & $\begin{array}{l}\text { MARUXA- Un velliño como'outro } \\
\text { non vin nunca en ningures. (p.23) }\end{array}$ \\
\hline 5. [...] bewildering light. (p.193) & {$[\ldots]$ meiga lus que abrouxa. (p.24) } \\
\hline $\begin{array}{l}\text { 6. [...] listen to her dreamy and strange } \\
\text { talk. (p.195) }\end{array}$ & $\begin{array}{l}{[\ldots] \text { que fala meiga, que estrana fala }} \\
\text { d'ensono a sua... (p.25) }\end{array}$ \\
\hline $\begin{array}{l}\text { 7. Shawn. I heard no steps but hers. } \\
\text { (p.201) }\end{array}$ & $\begin{array}{l}\text { XOAN —Non teño ouvido mais que as } \\
\text { suas meigas pegadas choutadoras. (p.27) }\end{array}$ \\
\hline
\end{tabular}

A tradución de queer por «como'outra/o non vin nunca en ningures» $(2,4)$, a énfase na estrañeza das fadas mediante a adición do adverbio «moi» (3) e a inclusión do adxectivo «meiga» en numerosas ocasións $(5,6,7)$ crean unha atmosfera que afonda no sobrenatural máis do que o fai o texto de partida. Do mesmo xeito, o adxectivo «achacio» para describir o brazo que se asoma pola porta (1) confírelle certos tons sinistros ao texto.

Neste sentido, hai que ter en conta a importante presenza que o paganismo, hipoteticamente herdado dos celtas, e o catolicismo tiñan na ideoloxía dos intelectuais galegos da época. Segundo Risco (1920a, p.7), o paganismo celta é a orixe do «sentimento relixioso da Terra» como reflexa a seguinte declaración onde o ideólogo ourensán cita a Unamuno:

[...] O paganismo que en ningures morreu, senón que se fixo bautizar cristianándose mais ou menos, latexa eiquí mais vivo que n-outras rexiós hespañolas, seica porque o antepasado do galego, un celta, tiña unha mitoloxía naturista que non tiña o beduíno, abó do castelao, o ibero rexo ...» 
A mitoloxía naturista celta é o xerme do amor pola terra que a eleva a unha esfera espiritual «Terra espiritualizada pol-o noso amore [...]» (Ibid, p.6) na que adquire valores relixiosos e, finalmente, é identificada con Deus:

Deus é a luz da espranza acesa detrás de nós... El non é Deus a esencia divina da nósa Terra, do nóso Lar? [...] D'iste xeito sentimol-a presencia evidente de deus na nósa Terra que se nos fai celeste e sagrada com'unha eirexa, porta da eternidade, tabernáculo da Gracia de Deus feita beleza. Os celtas, non erguían templos de pedra como os orientaes: a Terra era o seu templo... (Ibid, p.8)

Esta tripla asociación entre mitoloxía celta, relixión e terra, que se reflexa na tradución por medio da inclusión de referencias tanto ao catolicismo como aos poderes sobrenaturais pagáns, é un dos imperativos ideolóxicos da Xeración Nós e das Irmandades da Fala. A.Villar Ponte nas Liñas d'abrente do volume salienta este aspecto como un punto en común entre Galicia e Irlanda:

O complexo de tradición pagâ e d'espiritu cristián que fai compatible na terra de San Patrick o freixo escorrentador de meigas e trasnos co'a crús que escorrenta o demo, tan ben reflexado nos dous folk-dramas d'este volumen, ôs Galegos enxebres non ha de lles parecer estrano. (Yeats, 1935, p.3)

\subsection{Adición de trazos conversacionais}

\begin{tabular}{|c|c|}
\hline Texto orixe & Texto meta \\
\hline $\begin{array}{l}\text { 1. And is too deep just now in the old } \\
\text { book! (p.182) }\end{array}$ & $\begin{array}{l}{[\ldots] \text { está iludida d'abondo —n'hai }} \\
\text { senón vela- con ise libro vello. (p.19) }\end{array}$ \\
\hline 2. Maurteen. That's true - (p.185) & Mart. —É moi certo, abofellas (p.21) \\
\hline $\begin{array}{l}\text { 3. Bridget. She's given milk away. } \\
\text { (p.189) }\end{array}$ & $\begin{array}{l}\text { BRIXIDA —Pro ¿ti non ves? Déulles } \\
\text { leite. (p.22) }\end{array}$ \\
\hline 4. Maurteen. Who was it? (p.189) & $\begin{array}{l}\text { MART. 一Ora ¿quén era esa muller? } \\
\text { (p.22) }\end{array}$ \\
\hline 5. The butter is by your elbow. (p.190) & $\begin{array}{l}\text { Vel-ahí ten a manteiga a rentes da mán. } \\
\text { (p.22) }\end{array}$ \\
\hline $\begin{array}{l}\text { 6. Bridget. You've given milk and fire } \\
{[\ldots] \text { (p.190) }}\end{array}$ & $\begin{array}{l}\text { BRIXIDA -iCata que tal! Regalaches } \\
\text { leite e lume }[\ldots](\mathrm{p} .23)\end{array}$ \\
\hline 7. But you are welcome here. (p.195) & $\begin{array}{l}{[\ldots] \text { pro eiquí has ser, ña nena, para nós }} \\
\text { benvida. (p.25) }\end{array}$ \\
\hline
\end{tabular}

En ocasións os tradutores válense de adicións para crear un texto máis conversacional por medio de apelacións ao interlocutor $(5,7)$, preguntas retóricas (3), coloquialismos («ora», 4; «ña», 7), exclamacións (6), reiteracións (2). Por unha banda, estas adicións fan que o texto sexa máis fluído en galego e por outra, son un reflexo do imperativo ideolóxico de transformar unha lingua colo- 
quial e rural nun vehículo lexítimo no que poder transmitir a moderna literatura europea do momento.

\subsection{Adición de vocabulario expresións autóctonos}

\begin{tabular}{|l|l|}
\hline \multicolumn{1}{|c|}{ Texto orixe } & \multicolumn{1}{c|}{ Texto meta } \\
\hline$[\ldots]$ I have still some bottles. (p.183) & $\begin{array}{l}{[\ldots] \text { teño algunhas garrafas daquel aga- }} \\
\text { sallo d'o achar. (p.20) }\end{array}$ \\
\hline $\begin{array}{l}\text { After the fall of twilight on May Eve } \\
\text { (p.186) }\end{array}$ & $\begin{array}{l}{[\ldots] \text { no víspora do maio, despois d'anoi- }} \\
\text { tecido, entre fusco e lusco... (p.21) }\end{array}$ \\
\hline $\begin{array}{l}{[\ldots] \text { To watch the turf-smoke coiling }} \\
\text { from the fire, }[\ldots] \text { (p.190) }\end{array}$ & $\begin{array}{l}{[\ldots] \text { Ver rubir do lume as chamas tre- }} \\
\text { melantes e velaínas }[\ldots] \text { (p.23) }\end{array}$ \\
\hline Shawn. Be quiet, mother! (p.191) & $\begin{array}{l}\text { XOAN —iCale xa, miña nai! Non s'a- } \\
\text { rruce. (p.23) }\end{array}$ \\
\hline $\begin{array}{l}\text { Shawn. Do not blame me; I often lie awa- } \\
\text { ke } \\
\text { Thinking that all things trouble your } \\
\text { bright head }[\ldots] \text { (p.192) }\end{array}$ & $\begin{array}{l}\text {-No me culpes a min, ña meniña... Can- } \\
\text { tas veces estou esperto no leito, como se } \\
\text { esmagara espiñas, a matinare que tódal- } \\
\text { as cousas torvan ou acoran a tua testa } \\
\text { escintilante! (p.23) }\end{array}$ \\
\hline $\begin{array}{l}\text { Father Hart. My daughter, take his hand } \\
{[\ldots] \text { (p.193) }}\end{array}$ & $\begin{array}{l}\text { P. Hart -Miña filla, mina filla, colle a } \\
\text { sua man traballadora e apréixalla doce- } \\
\text { mente. (p.24) }\end{array}$ \\
\hline $\begin{array}{l}\text { All that bewilderment of light and free- } \\
\text { dom (p.193) }\end{array}$ & $\begin{array}{l}{[\ldots] \text { canto d'ise abrouxamento de lus e }} \\
\text { de libertade leva acochado no seo [... }] \\
\text { (p.24) }\end{array}$ \\
\hline
\end{tabular}

As adicións de expresións lingüísticas e vocabulario «puramente» galegos nas pasaxes anteriores amosan que a busca pola diferenciación determina as decisións dos tradutores aínda cando non hai motivación algunha por parte do texto orixe. Esta estratexia demostra ata que punto a tradución do drama popular responde ao imperativo político de promocionar e fortalecer a lingua galega como símbolo de identidade e proba da existencia de Galicia como nación.

\subsection{Adición de efectos líricos}

\begin{tabular}{|c|c|}
\hline Texto orixe & Texto meta \\
\hline $\begin{array}{l}\text { 1. Mary. I had no sooner hung it on } \\
\text { the nail } \\
\text { Before a child ran up out of the } \\
\text { wind; } \\
\text { She has caught it in her hand and } \\
\text { fondled it. }\end{array}$ & $\begin{array}{l}\text { Maruxa - No mesmo intre d'eu pen- } \\
\text { dural-a ponla do cravo una meniña be- } \\
\text { lida saiu correndo da veste do vento } \\
\text { que acariña as mestas somas do bos- } \\
\text { co; pillóuna co'a man esguía e bran- } \\
\text { ca, aloumiñándoa ô fuxire ... A }\end{array}$ \\
\hline
\end{tabular}




\begin{tabular}{|c|c|}
\hline Texto orixe & Texto meta \\
\hline $\begin{array}{l}\text { (Her face is pale as water before } \\
\text { dawn.) (pp.186-87) }\end{array}$ & $\begin{array}{l}\text { súa face é pálida, descôrada, com'a } \\
\text { i-auga denantes do abrente da } \\
\text { mañán.(p.21) }\end{array}$ \\
\hline $\begin{array}{l}\text { 2. Yet I could make you ride upon } \\
\text { the winds, } \\
\text { (Run on the top of the dishevelled } \\
\text { tide,) } \\
\text { And dance upon the mountains } \\
\text { like a flame. (p.202) }\end{array}$ & $\begin{array}{l}\text { [...] eu poido levarte cand'a min a } \\
\text { choutare d'acabalo dos ventos, na } \\
\text { compaña das brétemas, a correre } \\
\text { por riba do mar entr'a escuma das } \\
\text { olas, despeiteadas e lizgaira, e a bei- } \\
\text { lare no cumio dos montes com'unha } \\
\text { chama velaíña. (p.27) }\end{array}$ \\
\hline $\begin{array}{l}\text { 3. [...] When the leaves awaken } \\
\text { My mother carries me in her golden } \\
\text { arms. (p.203) }\end{array}$ & $\begin{array}{l}\text { Cando as follas despertan con risa- } \\
\text { das verdecentes, a miña nai lévame } \\
\text { d'aurora n'ocaso, nos seus brazos } \\
\text { dourados. (p.27) }\end{array}$ \\
\hline
\end{tabular}

As adicións introducidas nestes casos, que van dende a inserción de numerosos epítetos na mesma oración (1), ata a creación de personificacións («vento que acariña as mestas somas do bosco», 1) ou expansión das que xa existen no texto de partida («as follas despertan con risadas verdecentes», 3), non engaden ningún significado ao texto pero realzan o seu lirismo. En xeral, cumpren dúas funcións principais: compensar a perdas de trazos estilísticos por estar o texto traducido en prosa e non en verso como o orixinal, e cultivar e explotar a capacidade do galego como lingua literaria coa finalidade de elevar o seu estatus a lingua de cultura.

\subsection{Adicións que manipulan o significado do texto orixe}

Atopamos dous fragmentos na versión galega onde os tradutores empregan adicións para levar a cabo unha manipulación consciente do significado do texto orixe, que consiste en destacar determinados aspectos para adaptalo ao seu ideario político.

\begin{tabular}{|c|c|}
\hline Texto orixe & Texto meta \\
\hline $\begin{array}{l}\text { Faeries, come take me out of this dull } \\
\text { world, } \\
\text { For I would ride with you upon the wind, } \\
\text { (Run on the top of the disheveled tide, ) } \\
\text { And dance upon the mountains like a fla- } \\
\text { me. (p.192) }\end{array}$ & $\begin{array}{l}\text { ¡Fadas, levaime embora d'este mundo } \\
\text { tristeiro e melancónico, pois arelo c'oa i- } \\
\text { alma e o coraçón choutar velaína con- } \\
\text { vosco d'acabalo do vento, correr c'os } \\
\text { pes nuos na compaña da brétema encol } \\
\text { da xerfa risoña do mare, despeiteada e } \\
\text { leda e beilar com'unha chama sotil e } \\
\text { tremelucinte pol-o cumio dos montes. } \\
\text { (p.23) }\end{array}$ \\
\hline
\end{tabular}


Esta é unha pasaxe clave da obra, xa que é cando Mary expresa firmemente o seu desexo de fuxir dunha realidade opresiva e a súa arela pola liberdade representada polo mundo das fadas. Tendo en conta o paralelismo entre os desexos de Mary e a situación política de Galicia, que xa foi comentado con anterioridade, non é sorprendente que os tradutores salienten os sentimentos da moza con adicións do tipo «arelo c’oa i-alma e o coraçón», que lle dan máis forza aos desexos de liberdade e dealienación. As seguintes adicións «correr c'os pes nuos na compaña da brétema encol da xerfa risoña do mare» e «com'unha chama sotil e tremelucinte», amais de engadir efectos líricos, contribúen á idealización da terra das fadas, a terra que o corazón arela, e polo tanto reforzan o desexo de descolonización e redención.

\begin{tabular}{|l|l|}
\hline \multicolumn{1}{|c|}{ Texto orixe } & \multicolumn{1}{c|}{ Texto meta } \\
\hline I have these arms to hold you (p.208) & $\begin{array}{l}\text { teño estes brazos barudos como ponlas } \\
\text { de ferro para te atenacear (p.29) }\end{array}$ \\
\hline
\end{tabular}

Na mesma liña, a adición nesta pasaxe ten implicacións políticas importantes. Shawn está intentando convencer a Mary para que non marche coas fadas e quede con el, por iso lle ofrece os seus brazos para apreixala e que as fadas non lla poidan levar. Shawn é a conexión máis forte que Mary ten co seu cativerio, polo tanto a adición de «barudos como ponlas de ferro» para describir os brazos salienta a idea de opresión e convértese nun símbolo da situación de submisión na que Galicia se atopaba na época.

\section{OMISIÓNS}

Aínda que as omisións son escasas, deben ser analizadas por ser outro exemplo da capacidade manipuladora da tradución.

\begin{tabular}{|l|l|}
\hline \multicolumn{1}{|c|}{ Texto orixe } & \multicolumn{1}{c|}{ Texto meta } \\
\hline $\begin{array}{l}\text { My colleen, have not Fate and Time and } \\
\text { Change }\end{array}$ & $\begin{array}{l}{[\ldots] \text { ¿Non coidas, ña filla, que o Destiño }} \\
\text { Done well for me and for old Bridget the- } \\
\text { re? } \text { á vella Bríxida? (p.22) }\end{array}$ \\
\hline $\begin{array}{l}{[\ldots] \text { to the hour }} \\
\text { For bidding Fate and Time and Change } \\
\text { good-bye.) (p.190) }\end{array}$ & $\begin{array}{l}{[\ldots] \text { hastra que chega a hora no pasa- }} \\
\text { mento que un pecha os ollos para sempre } \\
\text { decíndolle adeus ó Destiño, ó Tempo e a } \\
\text { todo ... (p.23) }\end{array}$ \\
\hline
\end{tabular}

Nestas dúas pasaxes nas que Maurteen se refire a como o tempo, o destino e o cambio os trataron a el e a Bridget, os tradutores omiten a alusión ao concep- 
to de cambio. Hurtley (2006, p.90) fai unha lectura política desta omisión apuntando que...

The omission of the concept by the translators of The Land of Heart's Desire (O pais da saudade) in 1935 Republican Spain might be symptomatic of their anxiety with regard to a further change, which could jeopardize Galicia's chances of greater autonomy.

Tendo en conta que non hai ningún outro caso en toda a tradución que faga referencia a este hipotético medo a un cambio politico, a súa conclusión, fundamentada únicamente nesta omisión, é matizábel, sobre todo se consideramos que o concepto de cambio no texto orixe ten un sentido positivo. Parece máis probábel que os tradutores omitisen o termo simplemente porque é un concepto que normalmente, en galego, non iría asociado a termos como «destino» e «tempo» neste contexto, e polo tanto resultaríalles extraño o seu uso. Sexa como sexa, é unha nova mostra da tendencia dos tradutores a non someterse a xerarquía do texto de partida.

\begin{tabular}{|l|l|}
\hline \multicolumn{1}{|c|}{ Texto orixe } & \multicolumn{1}{|c|}{ Texto meta } \\
\hline $\begin{array}{l}\text { [Mary stands for a moment in the door } \\
\text { (and takes a sod of turf from the fire and } \\
\text { goes out through the door. [...] (p.190) }\end{array}$ & $\begin{array}{l}\text { Maruxa pilla un anaco de turba alcesa da } \\
\text { lareira e sai con ela fora da porta. (p.23) }\end{array}$ \\
\hline
\end{tabular}

Neste caso, a omisión da acotación que ocorre cando Mary lle da lume á vella estraña que ven do monte, amosa máis determinación no seu desexo de abandonar a mediocridade da súa situación. Cando a estraña criatura aparece, no texto orixe, Mary detense na porta por un momento, pero na tradución sae sen dubidalo, o que implica que non ten medo de seguir a súa arela de liberación.

\begin{tabular}{|l|l|}
\hline \multicolumn{1}{|c|}{ Texto orixe } & \multicolumn{1}{|c|}{ Texto meta } \\
\hline $\begin{array}{l}\text { Maurteen. There's some one singing. } \\
\text { Why, it's but a child. [...] }\end{array}$ & MART. - Escoita, que alguén and'a can- \\
$\begin{array}{l}\text { A strange song for a child, but she sings } \\
\text { sweetly. Listen, listen! (p.194) }\end{array}$ & tare [...] Cántiga meiga com'outra nunca \\
ouvín. (p.24)
\end{tabular}

Por último, neste fragmento no que Maurteen se refire á «Voz» que produce o son dunha canción, no texto de partida a voz identifícase cunha nena, a quen aínda non coñeceron, mentres que na tradución omítese esta identificación e, desta maneira, intensifícase o elemento sobrenatural do drama popular, xa que o lector-espectador non ten información de onde ven a voz. Este efecto refórzase coa tradución de strange por «meiga» e a adición de «com'outra nunca ouvín». 


\section{CONCLUSIÓN}

Para rematar, podemos dicir que $O$ pais da Saudade é un bo exemplo da tradución como proceso de apropiación, transformación e creación máis ca reprodución ou copia do orixinal. As estratexias tradutivas analizadas amósannos que «o 'outro', o 'alleo', non é tan importante en termos de 'equivalencia' senón en tanto a súa capacidade de amosa-los aspectos diferenciais e diferenciadores da lingua e da cultura galega» (Millán Varela, 1998, p.65). Os tradutores alteran tanto a lingua como o contido do texto de partida, posto que só desta maneira poden cumprir o seu obxectivo de lexitimar e reforzar a lingua e de incorporar o espíritu celta á tradición literaria autóctona. Esta práctica da tradución como forma de loita, resistencia e reafirmación da identidade é unha actividade transcultural que se move en dúas direccións (Vieira, 1999, p.106) e na cal se rompe a xerarquía entre orixinal e tradución. O efecto que produce este proceso é a creación dun espazo intermedio onde converxen dous mundos e dúas culturas (Irlanda e Galicia), tal e como explica Samia Menhrez (1992, p.110) cando se refire ás literaturas postcoloniais anglófonas e francófonas:

By drawing on more than one culture, more than one language, more than one world experience, within the confines of the same text, postcolonial anglophone and francophone literature very often defies our notions of an 'original' and its translation.

Aínda que o contexto é diferente, este argumento é totalmente aplicable ao caso galego debido as desiguais relacións de poder que existían na época. Desafiando esta xeraquía entre o orixinal e a súa tradución, Plácido Castro e os irmáns Villar Ponte, comprometidos coa realidade socio-política da Galicia do seu tempo, empregaron a tradución como un instrumento político descolonizador tomando como referencia os modelos irlandeses e apropiándose deles, de maneira que lles servisen para amosar as características diferenciais da lingua e cultura galegas como proba da existencia de Galicia como unha nación cunha identidade propia.

\section{APÉNDICE}

\begin{tabular}{|l|l|l|}
\hline \multicolumn{1}{|c|}{ Texto orixe } & \multicolumn{1}{c|}{ Texto meta } & Outras solucións posíbeis \\
\hline alcove (p.180) & ban (p.19) & alcoba \\
\hline on the floor (p.180) & encol do chao (p.19) & no / sobre o chao \\
\hline benches/ bench (p.180) & sentadoiros/ tallo (p.19) & bancos \\
\hline table (p.180) & táboa (p.19) & mesa \\
\hline a glow of light & o escentileio das & o brillo da luz do lume \\
\hline from the fire (p.180) & labaradas do lume (p.19) & \\
\hline sit (p.180) & áchanse pousando (p.19) & sentados \\
\hline
\end{tabular}




\begin{tabular}{|c|c|c|}
\hline Texto orixe & Texto meta & Outras solucións posíbeis \\
\hline at the table (p.180) & acarón da táboa (p.19) & á mesa \\
\hline $\begin{array}{l}\text { dressed in the costume } \\
\text { (p.180) }\end{array}$ & $\begin{array}{l}\text { adobiados con fatelos } \\
\text { (p.19) }\end{array}$ & vestidos con roupa/traxes \\
\hline near them (p.181) & rentes deles (p.19) & cerca deles \\
\hline boisterous night (p.182) & $\begin{array}{l}\text { noite de corisco e chuvia } \\
\text { (p.19) }\end{array}$ & noite de tormenta \\
\hline but do not blame her (182) & $\begin{array}{l}\text { non compre asoballala } \\
\text { (19) }\end{array}$ & pero non a culpes \\
\hline to vex her (p.182) & que s'encabuxe (p.19) & que se enfade \\
\hline head (p.183/p.192) & testa (p.20/p.23) & cabeza \\
\hline heard (p.184) & ouvíu (p.20) & oíu \\
\hline put it away (p.184) & arreda (p.20) & aparta \\
\hline spreads (p.184) & inza (p.20) & estende \\
\hline flattered (p.185) & $\begin{array}{l}\text { engaiolou }[\ldots] \text { hastra o } \\
\text { iludire (pp.20-21) }\end{array}$ & adulou/ seduciu \\
\hline maybe (p.185) & cicais/ cecais (p.21) & quizais, quizá \\
\hline a turn (p.185) & miaxa de laboura (p.21) & traballo \\
\hline lies (p.186) & argalladas (p.21) & mentiras \\
\hline at the fire (p.186) & rentes do lume (p.21) & aredor do lume \\
\hline seat (p.186/p.192) & tallo (p.21/p.23) & asento \\
\hline hung it (p.186) & $\begin{array}{l}\text { dependúraa/ pendura-la } \\
\text { (p.21) }\end{array}$ & cólgaa \\
\hline dressed (p.186) & enfeitada (p.21) & vestida \\
\hline I am glad (p.187) & fólgome moito (p.21) & alégrome \\
\hline fight with them (p.187) & $\begin{array}{l}\text { escorrentalas n'unha gran } \\
\text { loita (p.21) }\end{array}$ & loitar con elas \\
\hline there (p.188) & acolá (p.22) & alí \\
\hline wicked (p.188) & desavegosa (p.22) & malvada \\
\hline while (p.188) & entramentras (p.22) & mentres \\
\hline face (p.189)/ face (p.190) & face (p.22)/ faciana (p.22) & cara \\
\hline hereabout (p.189) & bisbarra (p.22) & arredores \\
\hline Hidden away (p.189) & alapadas (p.22) & escondidas \\
\hline ribbons (p.190) & adovíos (p.22) & adornos \\
\hline
\end{tabular}




\begin{tabular}{|c|c|c|}
\hline Texto orixe & Texto meta & Outras solucións posíbeis \\
\hline Do not be cross (p.190) & non te arruces (p.22) & non te enfades \\
\hline with him (p.190) & cand'a sí (p.22) & consigo \\
\hline We long (p.190) & arelamos (p.23) & desexamos \\
\hline way (p.190/p.206) & vieiro (p.23/p.28) & camiño \\
\hline chill (p.191) & friaxe (p.23) & frío \\
\hline shiver (p.191) & chavear receioso (p.23) & tremer, tremar \\
\hline kind (p.192) & amabel (p.23) & amable \\
\hline I'd hang (p.193) & penduraríame (p.24) & colgaríame \\
\hline hearths (p.193) & casás (p.24) & fogares \\
\hline $\begin{array}{l}\text { if you would have it } \\
\text { (p.193) }\end{array}$ & si ti o degoirabas (p.24) & se ti o desexases \\
\hline I would mould (p.193) & arranxaría (p.24) & moldearía \\
\hline bitter (p.193) & dicaz (p.24) & mordaz \\
\hline over-wise (p.193) & sabio d'abondo (p.24) & demasiado sabio \\
\hline lonely (p.193) & soedosa e senlleira (p.24) & soa \\
\hline beam (p.194) & raiola (p.24) & raio \\
\hline $\begin{array}{l}\text { the indissoluble sacra- } \\
\text { ment (p.194) }\end{array}$ & $\begin{array}{l}\text { o rexo vencello do casa- } \\
\text { mento (p.24) }\end{array}$ & o indisoluble sacramento \\
\hline proud (p.194) & guarido (p.24) & orgulloso \\
\hline pale lights (p.195) & luces abazanadas (p.25) & luces pálidas, tenues \\
\hline bewildering (p.195) & que aterrece (p.25) & que desconcerta \\
\hline pretty (p.196) & belida (p.25) & bela \\
\hline coaxing ways (p.197) & $\begin{array}{l}\text { lanzal, feituca e soler- } \\
\text { meira (p.25) }\end{array}$ & aduladora \\
\hline cross (p.197) & cheia de cabuxo (p.25) & enfadada \\
\hline please (p.197) & gorentarían (p.26) & gustarían \\
\hline but (p.197) & en troques (p.26) & pero \\
\hline idle (p.197) & $\begin{array}{l}\text { nugalláns e preguiceiros } \\
\text { (p.26) }\end{array}$ & folgazáns \\
\hline $\operatorname{sigh}(\mathrm{p} .198)$ & salaiar a esguello (p.26) & suspirar \\
\hline $\operatorname{sip}(\mathrm{p} .198)$ & groulo (p.26) & sorbo, trago \\
\hline
\end{tabular}




\begin{tabular}{|c|c|c|}
\hline Texto orixe & Texto meta & Outras solucións posíbeis \\
\hline dance (p.198) & beilar (p.26) & bailar \\
\hline caressing (p.199) & aloumiñando (p.26) & acariciar, acariñar \\
\hline take fright (p.199) & que se abraia (p.26) & que se asusta \\
\hline so keen-witted (p.200) & $\begin{array}{l}\tan \text { lizgaira e tan aguda } \\
\text { (p.27) }\end{array}$ & perspicaz, enxeñosa \\
\hline you'll soon learn (p.200) & $\begin{array}{l}\text { deprenderás de contado } \\
\text { (p.27) }\end{array}$ & aprenderás pronto \\
\hline trouble (p.200) & acorâse (p.27) & preocuparse, molestarse \\
\hline here (p.200/p.201) & veleiquí (p.27/p.27) & aquí \\
\hline $\begin{array}{l}\text { small steps beating } \\
\text { (p.201) }\end{array}$ & $\begin{array}{l}\text { pasiños que tripaban } \\
\text { (p.27) }\end{array}$ & pasiños que pisaban \\
\hline floor (p.201) & astrago (p.27) & chan \\
\hline $\begin{array}{l}\text { I will give you somet- } \\
\text { hing (p.201) }\end{array}$ & $\begin{array}{l}\text { heiche de regalare una } \\
\text { moi linda lilaina. (p.27) }\end{array}$ & heiche de regalar algo \\
\hline yes (p.201) & abofé (p.27) & si \\
\hline wish (p.204) & degaro (p.28) & desexo \\
\hline ears (p.205) & ouvidos (p.28) & oído \\
\hline you're crouching (p.206) & encollidiña (p.28) & agachada \\
\hline $\begin{array}{l}\text { drift into the mind } \\
\text { [thoughts] (p.206) }\end{array}$ & $\begin{array}{l}\text { buligan pol-a nosa mente } \\
\text { (p.28) }\end{array}$ & vagan pola nosa mente \\
\hline pride (p.210) & fachenda (p.30) & orgullo \\
\hline
\end{tabular}

\section{REFERENCIAS BIBLIOGRÁFICAS}

Alspach, R.K. + Alspach C.C. (eds) (1966) The Variorum Edition of the Plays of W.B.Yeats. Londres: Macmillan.

Álvarez Lugrís, A. (2005) 'Galicia, Irlanda e o Leabhar Gabhala. O mito celta no proceso de construción da identidade nacional galega', en Gómez Penas, $\mathrm{M}^{\mathrm{a}} \mathrm{D}$. (coord.) A identidade galega e irlandesa a través dos textos. Galician and Irish Identity through texts. Santiago de Compostela: Servizo de publicacións e intercambio científico, Universidade de Santiago de Compostela, pp. 55-92.

Anderson, B. (2006) Imagined Communities. Londres: Verso.

Baker, M. (ed.) (1998) Encyclopedia of Translation Studies. Londres e Nova York: Routledge. 
Bassnett, S. (1985) 'Ways through the labyrinth. Strategies and methods for translating theatre texts', en Hermans, Th. (ed.) The Manipulation of Literature. Studies in Literary Translation. Londres: Croom Helm Ltd, pp. 87103.

Canedo, J. (1930) «A Lingüística e o Nazonalismo», Nós, 84, pp. 236-239.

Castro, P. (1927a) ‘Saudade y Arte I’, El Pueblo Gallego, 1143, pp. 1-2.

- (1927b) 'Saudade y Arte II', El Pueblo Gallego, 1155, p.2.

- (1927c) ‘Saudade y Arte III', El Pueblo Gallego, 1178, pp.1-2.

Cuveiro Piñol, J. (1876) Diccionario Gallego. Barcelona. En Diccionario de diccionarios - Corpus lexicográfico la lingua galega. [En liña] http://sli.uvigo.es/DdD/index.html (consultado: 14 febreiro 2011).

Feixó Cid, X. (2005) As Nomas Ortográficas e Morfolóxicas da Lingua Galega. Actualización, complementos e desviacións. $5^{\mathrm{a}}$ edn. Vigo: edicións do cumio.

Filgueira Valverde, X. + Tobío Fernandes, L., Magariños Negreira, A. e Cordal Carús, X. (1926) Vocabulario popular castelán-galego (publicado por entregas en El Pueblo Gallego). En Diccionario de diccionarios - Corpus lexicográfico la lingua galega. [En liña] http://sli.uvigo.es/DdD/index.html (consultado: 14 febreiro 2011).

Hurtley, J.A. (2006) 'Lands of Desire: Yeats in Catalonia, Galicia and the Basque Country 1920-1936' en Jochum, K.P. (ed.) The Reception of W.B. Yeats in Europe. Londres e Nova York: Continuum, pp. 76-95.

Mehrez, S. (1992) 'Translation and the postcolonial experience: the francophone North African text', en Venuti, L. (ed.) Rethinking Translation: Discourse, Subjectivity, Ideology. London: Routledge, pp.120:138.

Millán Varela, C. (1997) «Linguistic Evidences of a Conflict in the Galician Ulysses» en Simms, K. (ed.) Translating sensitive texts: Linguistic Aspects. Approaches to Translation Studies. Amsterdam e Atlanta: Editions Rodopi BV, vol. 14, pp. 283-292.

- (1998) «Nacionalismo versus universalismo nos anacos galegos do Ulysses», Viceversa, 4, pp. 59:76.

Muñoz Carrobles, D. (2008) «Evolución e cambios na normativa oficial do galego (1982-2007)», Madrygal: Revista de Estudios Gallegos, 11, pp. 49-56 [En liña]

http://revistas.ucm.es/fl1/11389664/articulos/MADR0808110049A.PDF (Consultado: 27 outubro 2010).

Murguía, M. (1979 [1888-1901]) Historia de Galicia, 5 volumes. Bilbao: La Gran Enciclopedia Vasca.

Nós (1920a) «Primeiras verbas», 1, pp. 1-2.

Nós (1920b) «Letras irlandesas. W.B.Yeats», 3, pp. 15-16. 
Portela Valladares, M. (1923) «En col da lingua galega», Nós, 17, pp.2-6.

Risco, V. (1920a) 'O sentimento da terra na raza galega', Nós, 1, pp. 4-9.

- (1920b) «Prosas galeguistas. Limiares», A Nosa Terra, 109, p.12.

- (1921) 'Nós, os inadaptados', Nós, 8, pp. 115-123.

Robinson, D. (1997) Translation and Empire: Postcolonial Theories Explained. Manchester: St. Jerome Publishing.

Rodríguez González, E. (1958-1961) Diccionario enciclopédico gallego-castellano. Vigo: Galaxia. En Diccionario de diccionarios - Corpus lexicográfico la lingua galega. [En liña] http://sli.uvigo.es/DdD/ddd_pescuda.php?pescuda=lilaina\&tipo_busca=lema (consultado: 27 outubro 2010).

Verea y Aguiar, J. (1838) Historia de Galicia. Ferrol: D. Nicasio Taxonesa.

Vicetto, B. (1986 [1865]) Historia de Galicia: Tomo 1. A Coruña: Xuntanza Editorial.

Vieira, E. R. P. (1999) «Liberating Calibans: Readings of Antropofagia and Haroldo de Campos' Poetics of Transcreation.» en Bassnett, S. e Triverdy H. (eds) Post-Colonial Translation: Theory and Practice. Londres: Routledge, pp. 95-113.

Villar Ponte, A. (1917) «Ferrol-Cruña. Unha nova xornada galleguista. O enxebrismo tragueranos o progreso e a libertá», A Nosa Terra, 10, pp. 1-5.

- (1927) 'Galerías. Sobre las orientaciones de nuestro teatro', El Pueblo Gallego, 968, pp. 1-2.

Yeats, W.B. (1927) La terra del desig. Traducido por Marià Manent. La Revista, Any XIII (xullo-decembro), pp. 122-132.

- (1935) Dous folk dramas de W.B. Yeats vertidos â língoa galega direitamente do inglés por Plácido Castro e os irmáns Vilar Ponte, con licencia do autor. Santiago de Compostela: Nós. 
